\title{
5. DEVELOPMENT OF SURVEY INSTRUMENT
}

Figure 1 outlines the process used to develop the survey instrument.

\section{Development of Content Areas}

\section{Development of criteria for selection of content areas}

A comprehensive list of all possible content areas for the survey was developed, based on a review of current child health policy documents at both state and national levels. The CHSTEG developed criteria to select content areas for the New South Wales Child Health Survey as follows:

- a priority for child health as documented in a state or national child health policy;

- meets the information needs of the NSW Department of Health, the 17 area health services, or other organisations dealing with child health;

- information is not readily available from other sources;

- estimated sample size in the New South Wales Child Health Survey is large enough to provide data that can be used to generalise responses to the NSW population aged $0-12$ years;

- the information is not highly sensitive or likely to cause failure to complete the survey.

To be included in the survey, the proposed content areas needed to meet all of the listed criteria, except for the demographic section, which was already considered high priority. The content area of social capital was added to the survey further along the process, so it was also not considered against the criteria.

\section{Application of criteria to content areas}

Criterion 1: A priority for child health as documented in a state or national child health policy

To identify potential content areas to include in the New South Wales Child Health Survey, existing state and national policies and child and family health reports were reviewed. These documents included:

- The Health of Young Australians: A national health policy for children and young people; ${ }^{2}$

- Health Goals and Targets for Australian Children and Youth $;^{6}$

- The National Health Plan for Young Australians, $;^{7}$

- Caring for health: Caring for children. A discussion paper towards the development of a child health policy for $N S W ; 8$

- The start of good health: Improving the health of children in $N S W^{9}$

- A survey of experts in child population health conducted by the Division of Population Health, Central Sydney Area Health Service, regarding important indicators to monitor for child health. ${ }^{10}$
Using these documents, a list of proposed content areas for the New South Wales Child Health Survey was prepared for consideration by the CHSTEG. The proposed content areas were grouped into three sections: risk factors and behaviours; health status; and health service use. The proposed content areas included: injury, sun exposure, immunisation, nutrition, physical activity, maternal factors, sudden infant death syndrome (SIDS), drug use (smoking, alcohol and other drugs), parent-child interaction, general health, disability, mental health, asthma, oral health, low birthweight, bowel problems, weight, early childhood centres, emergency departments, hospitals, general practitioners, access to health services, parental involvement in health care decision-making, and access to parental support services. Table 1 outlines whether the content area was considered to be a priority, based on this documentation. Some content areas were state priorities for adult health but have their origins in childhood.

Criterion 2: Meets the information needs of the NSW Department of Health, the 17 area health services, and other organisations dealing with child health

The proposed content areas were assessed by the CHSTEG and the area health service contacts according to their information needs. The CHSTEG were asked to rank content areas as: $3=$ high; $2=$ medium; $1=$ low; or $0=$ not applicable for infants $(0<1$ years), children aged $1-4$ years and children aged 5-12 years. Area health service contacts were asked to rank content areas in the same way for children aged $0-12$ years overall. The result of the prioritisation exercise was a CHSTEG score by age group and an overall area health service score for children aged $0-12$ years for each proposed content area. The CHSTEG and area health service scores were expressed as an average overall ranking for each content area (Table 1).

\section{Criterion 3: Information not readily available from other sources}

The degree to which including the content area in the New South Wales Child Health Survey would help to bridge information gaps and provide useful information that could not be sourced elsewhere in NSW or Australia was determined. Three recent documents outlining aspects of child and youth health and wellbeing were reviewed to assist this process: Australia's Children: their health and wellbeing, ${ }^{1}$ The Health of the People of NSW: Report of the NSW Chief Health Officer 1997;11 and Children, Australia: a social report. ${ }^{12}$ In addition, work of the Australian Institute of Health and Welfare on developing a national child health information framework was considered..$^{13}$ Available information on the proposed content areas was documented so as to determine potential information gaps (Table 1). No information at a population level was available for contact sport injuries and use of 


\section{FIGURE 1}

\section{FLOW CHART OF STEPWISE PROCESS OF SURVEY INSTRUMENT DEVELOPMENT}

\section{Step 1: Development of content areas}

Develop criteria for selection of content areas

- Documented in state or national policy

- Meets information needs

- Content not available elsewhere

- Estimated sample size in Child Health Survey large enough

- Information not highly sensitive

Step 2: Development of questions

Develop question inclusion criteria:

- Question provides most useful and important information on the content area

- Question is suitable for phone administration

- Question is reliable when reported by proxy

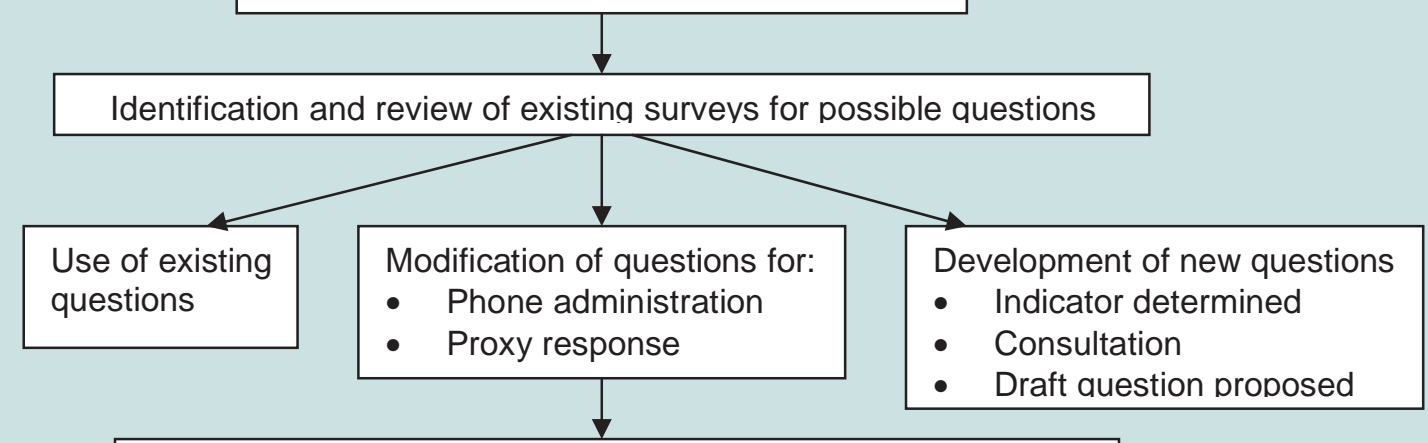

Application of question inclusion criteria to proposed questions

Step 3: review of all questions and pilot of survey instrument

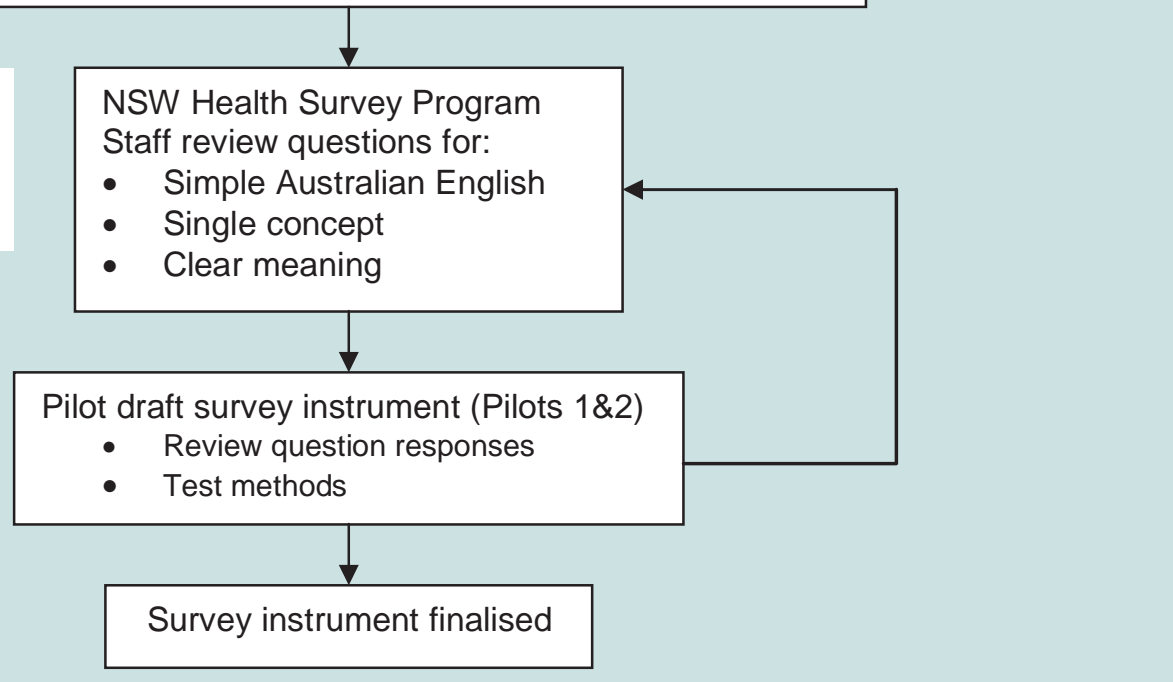


preventative measures for these, infant feeding difficulties, maternal use of folate in pregnancy, attendance at early childhood centers, access to healthcare when needed, health related parental decision making, access to parental support services; and minimal information was available on physical activity levels in children.

Criterion 4: Estimated sample size in the survey large enough to provide data that can be used to generalise responses to the NSW child population

The following documents: Australia's Children: their health and wellbeing; ${ }^{1}$ The health of the people of New South Wales-Report of the NSW Chief Health Officer 1997: ${ }^{11}$ and Children, Australia: A social report, ${ }^{12}$ were reviewed for prevalence and incidence data, in order to estimate the approximate sample size for each proposed content area. The information needs of different age groups (Criteria 2), and the potential for sub-setting of information (Table 1) was also considered when estimating sample sizes that might be achieved. Any proposed content areas with small estimated sample sizes were excluded from the final survey. The sample estimate was less than 50 for injury information on lead exposure, burns and scalds, drowning, and motor vehicle accidents. Sample estimates could not be calculated where information was not available to give prevalence or incidence estimates.

Criterion 5: The information is not highly sensitive or likely to cause failure to complete the survey

NSW Health Survey Program staff subjectively reviewed all the proposed content areas for their sensitivity. Content areas were ranked highly sensitive (HS), mildly sensitive (MS) or not sensitive (NS) in terms of their administration by telephone (Table 1). No content areas were rated as highly sensitive, and while some content areas-such as maternal factors, environmental tobacco smoke exposure, parental knowledge of sleeping positions and risk of sudden infant death syndrome (SIDS), parental drug and alcohol use and attitude to drug and alcohol use by children, parent-child interaction, general health status, mental health status and bowel problems-were considered mildly sensitive, none were considered to be too sensitive to include in the survey.

Continued on page 21 


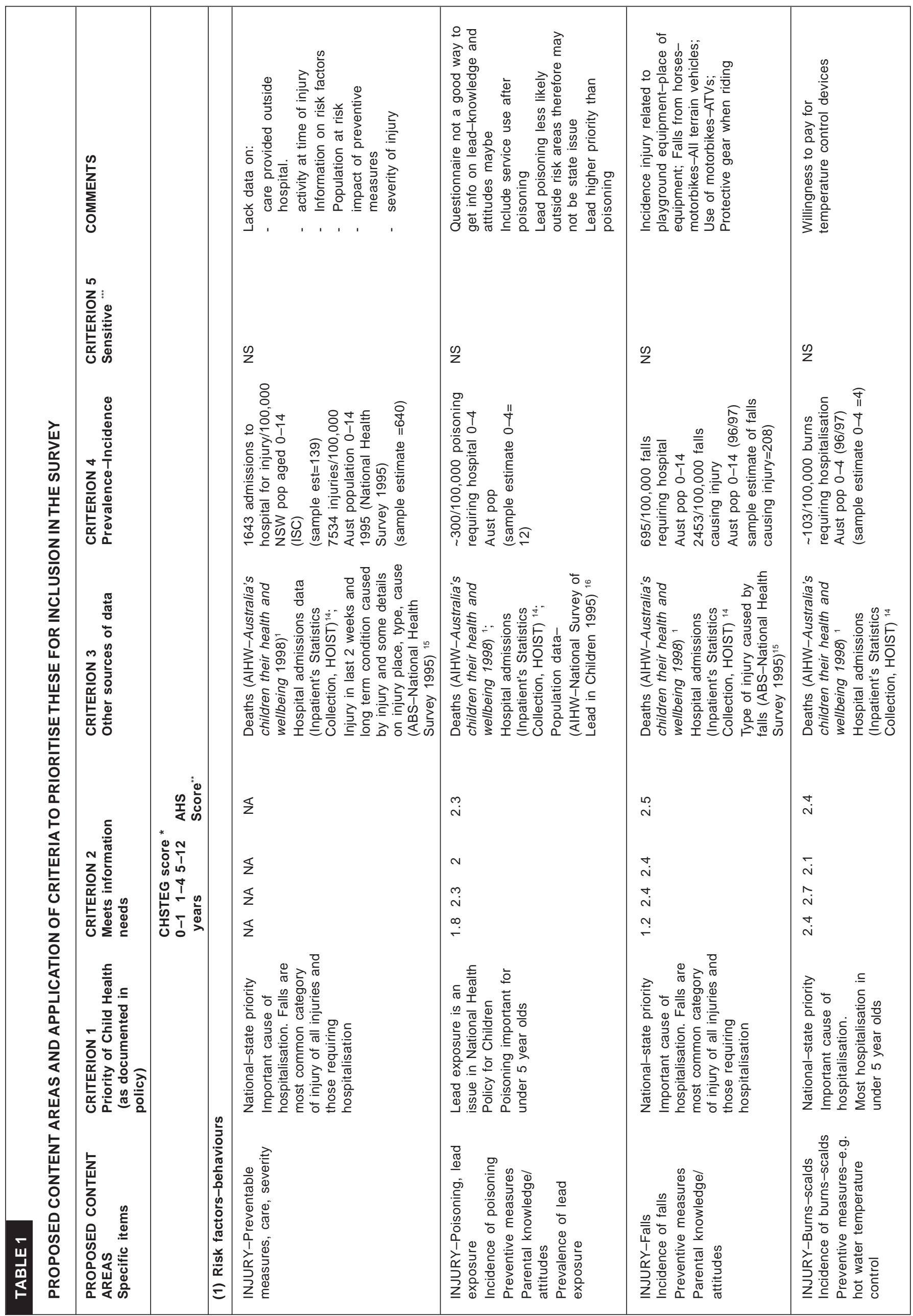




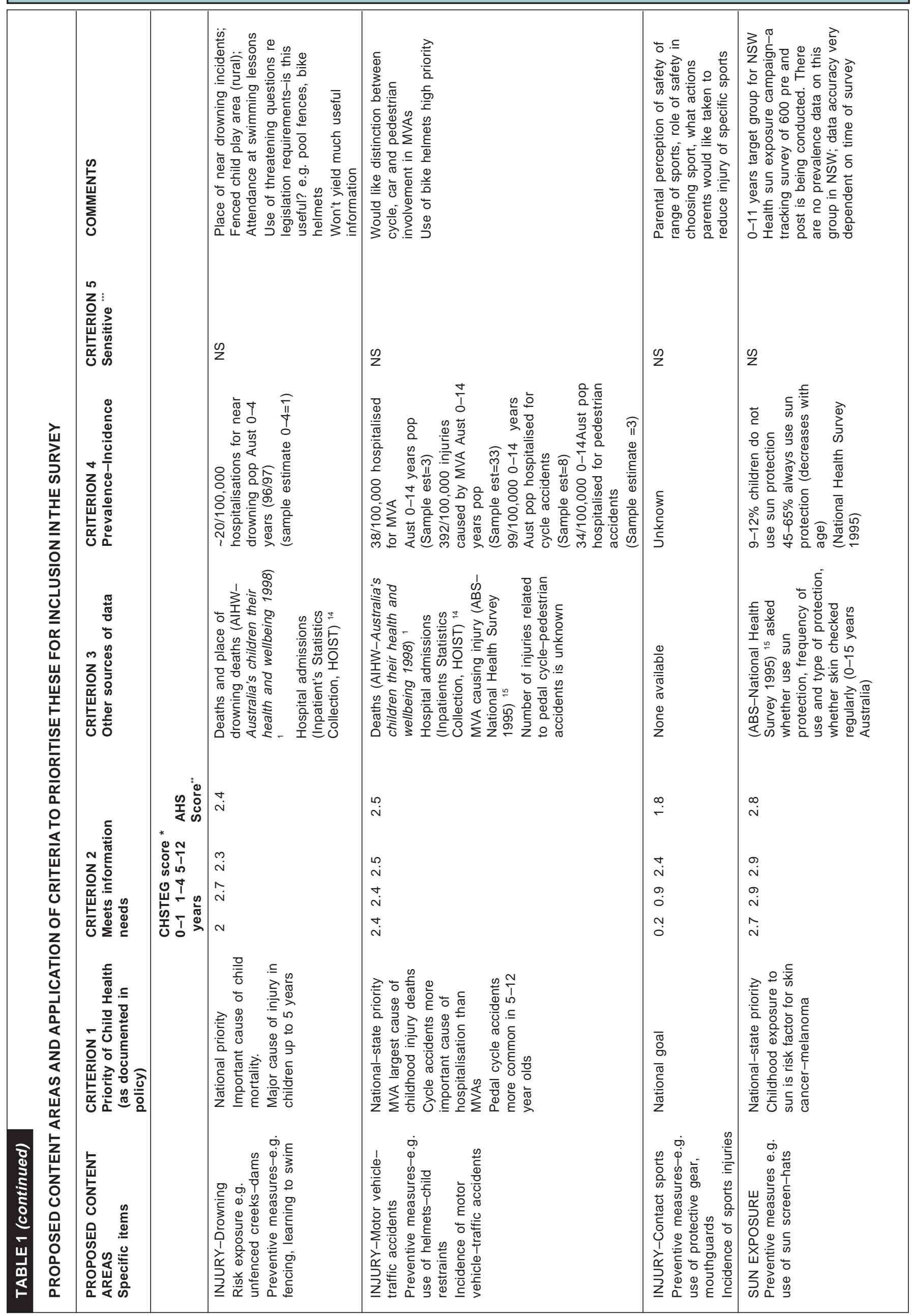




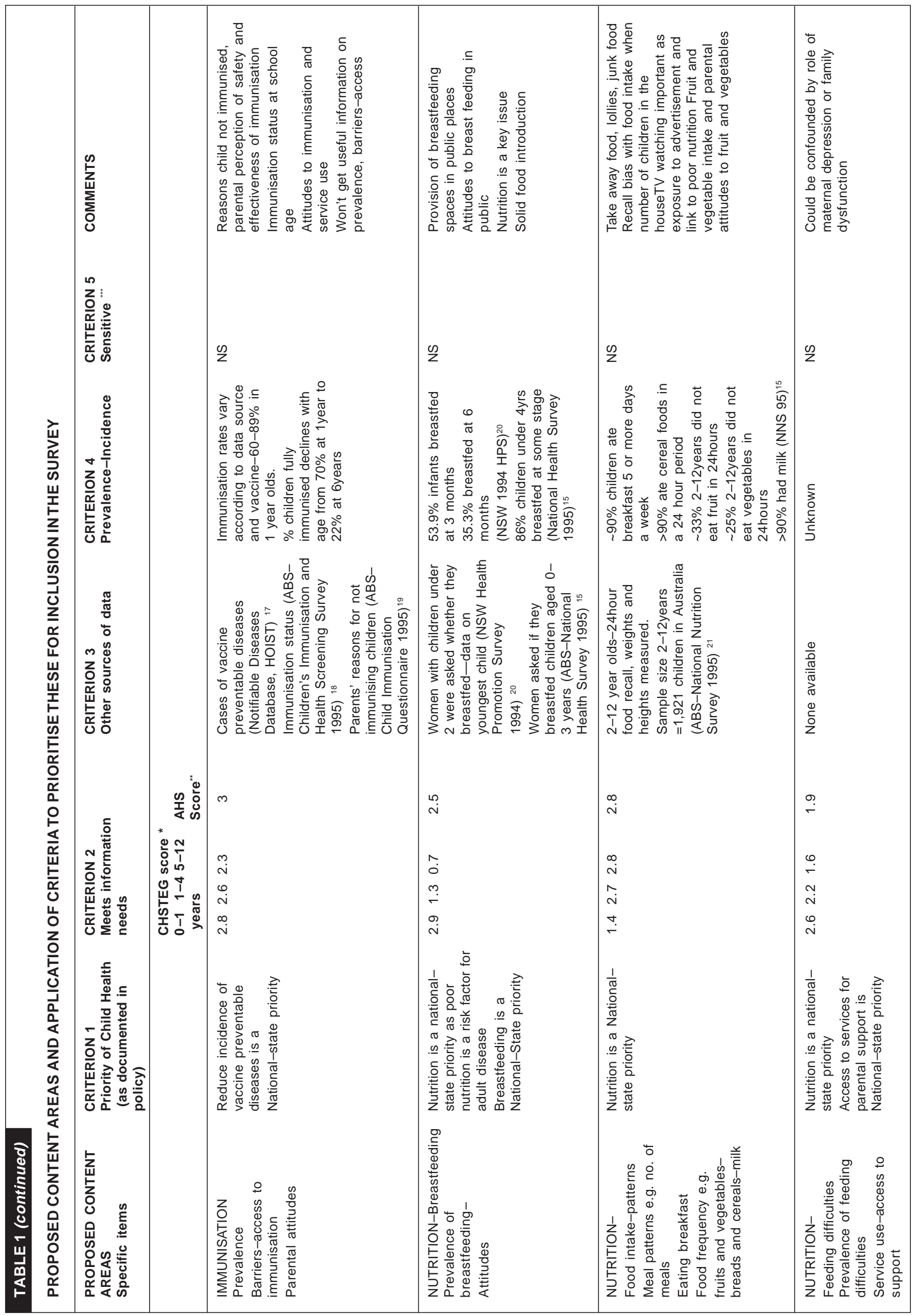




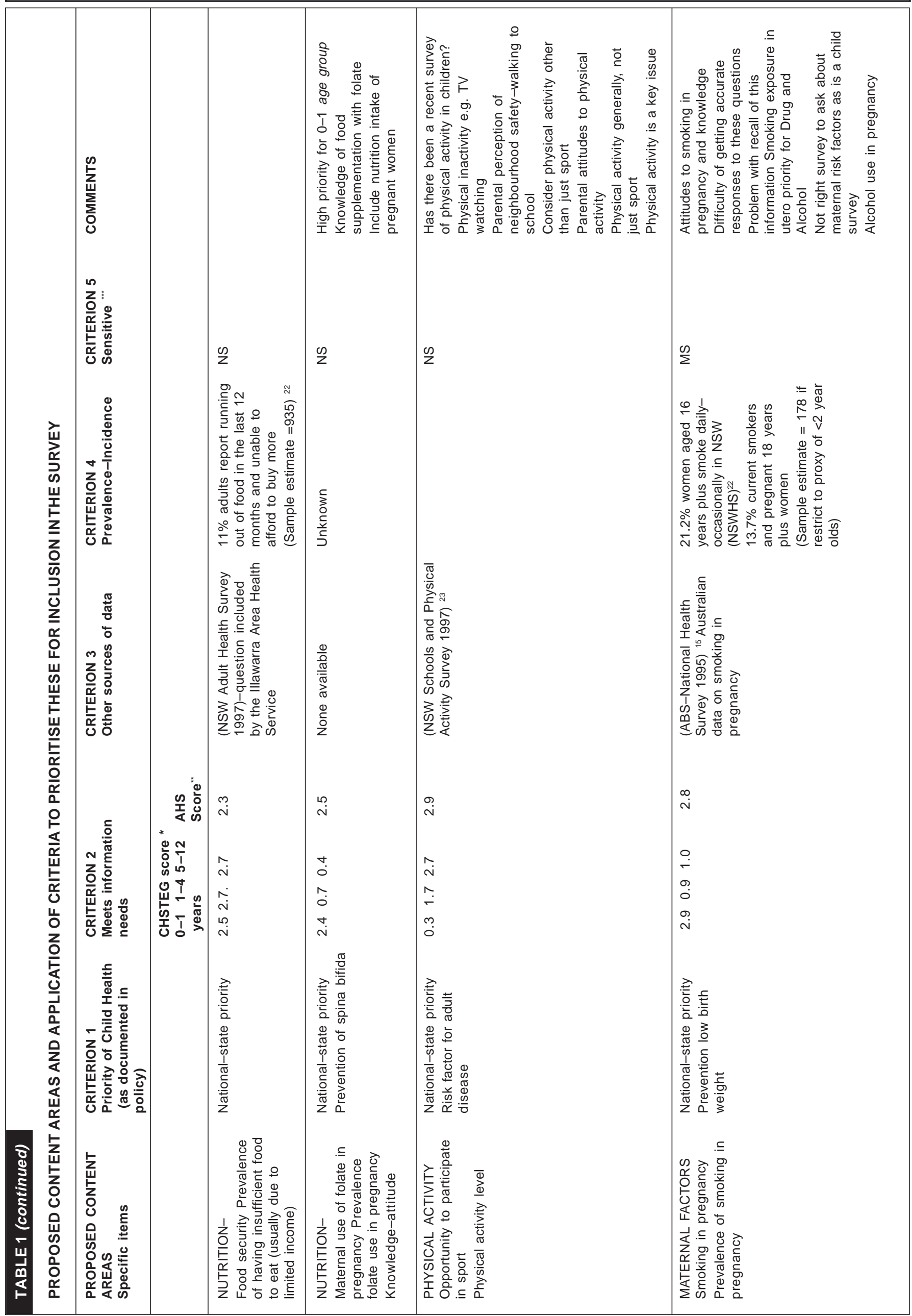




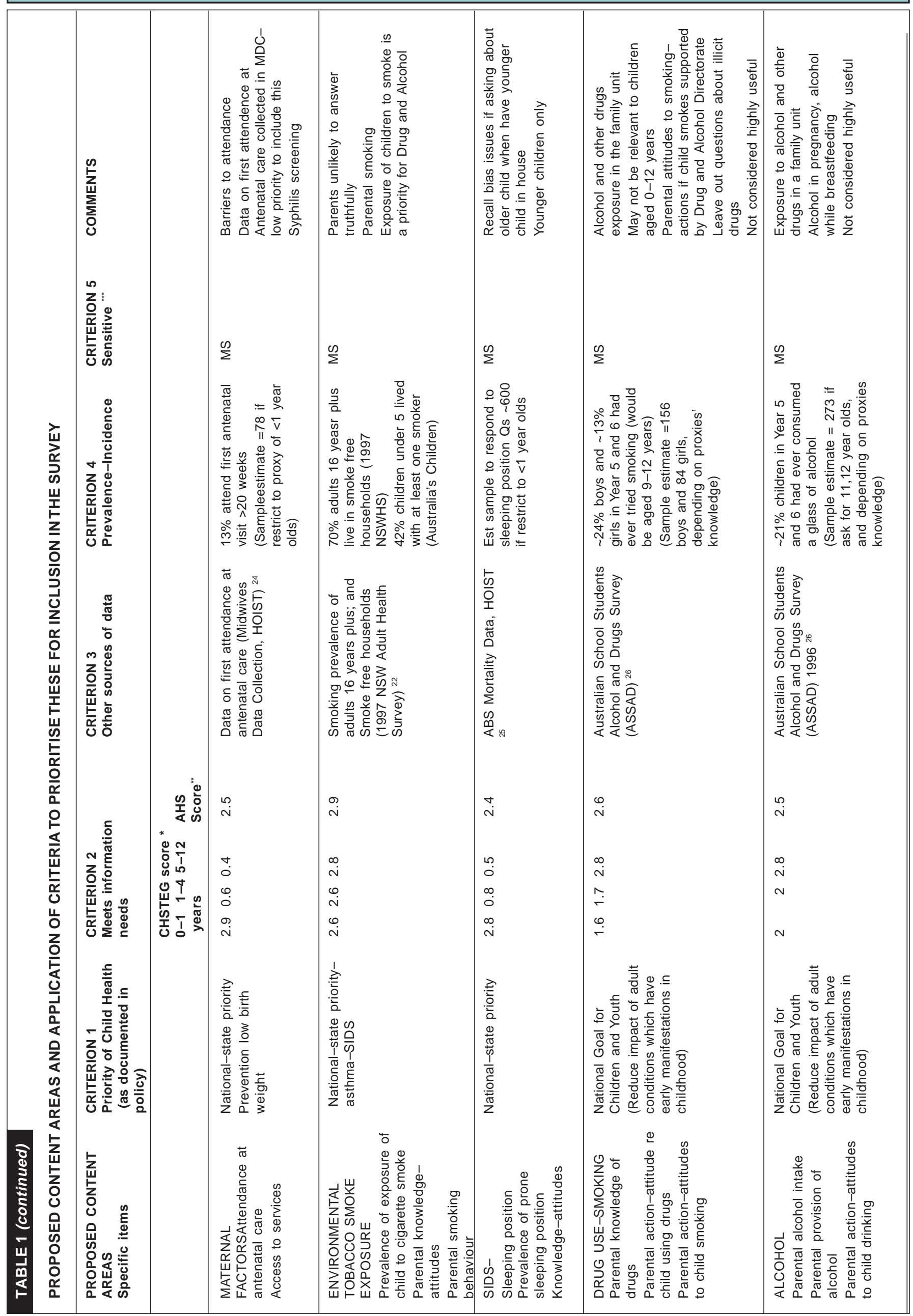




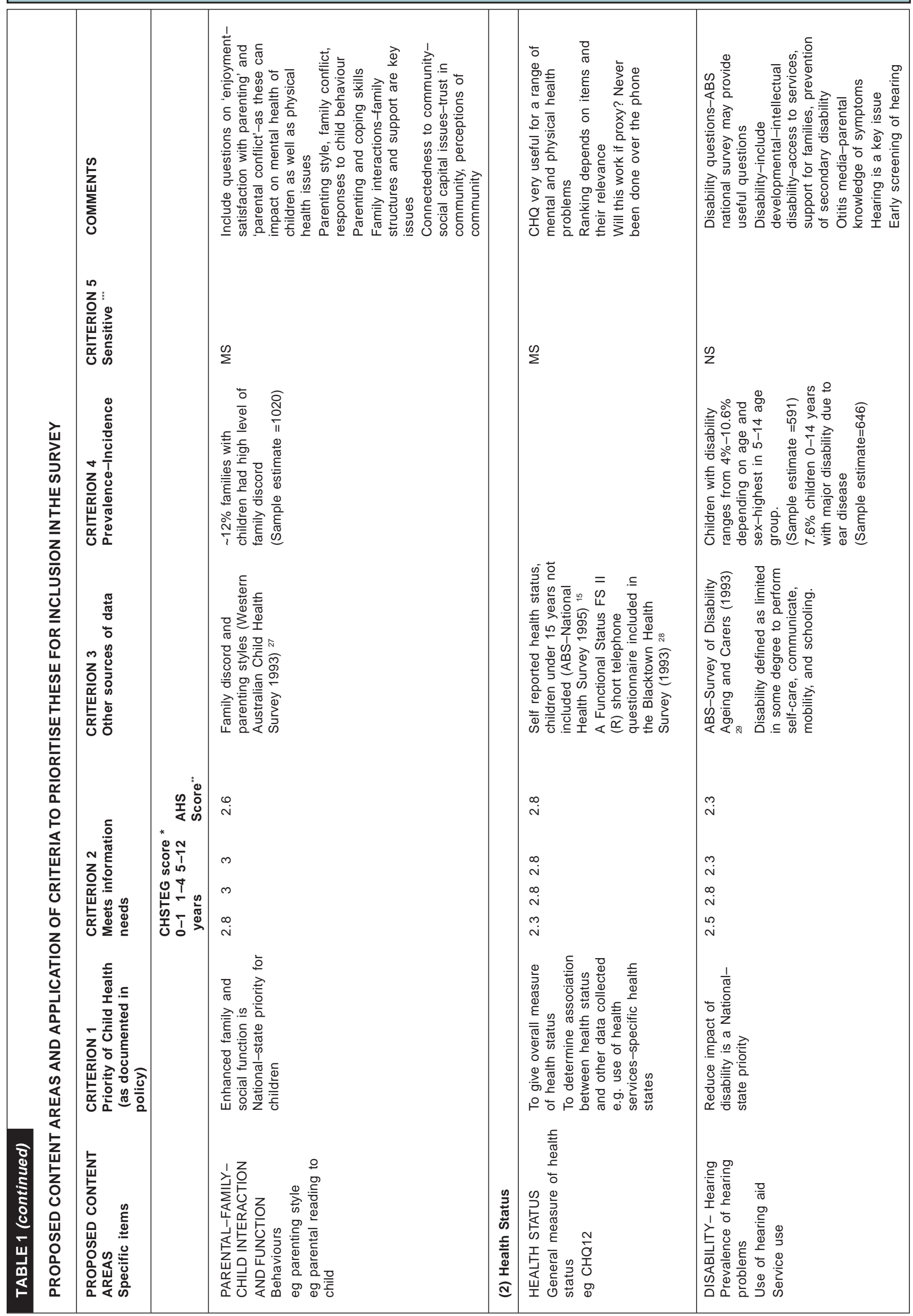




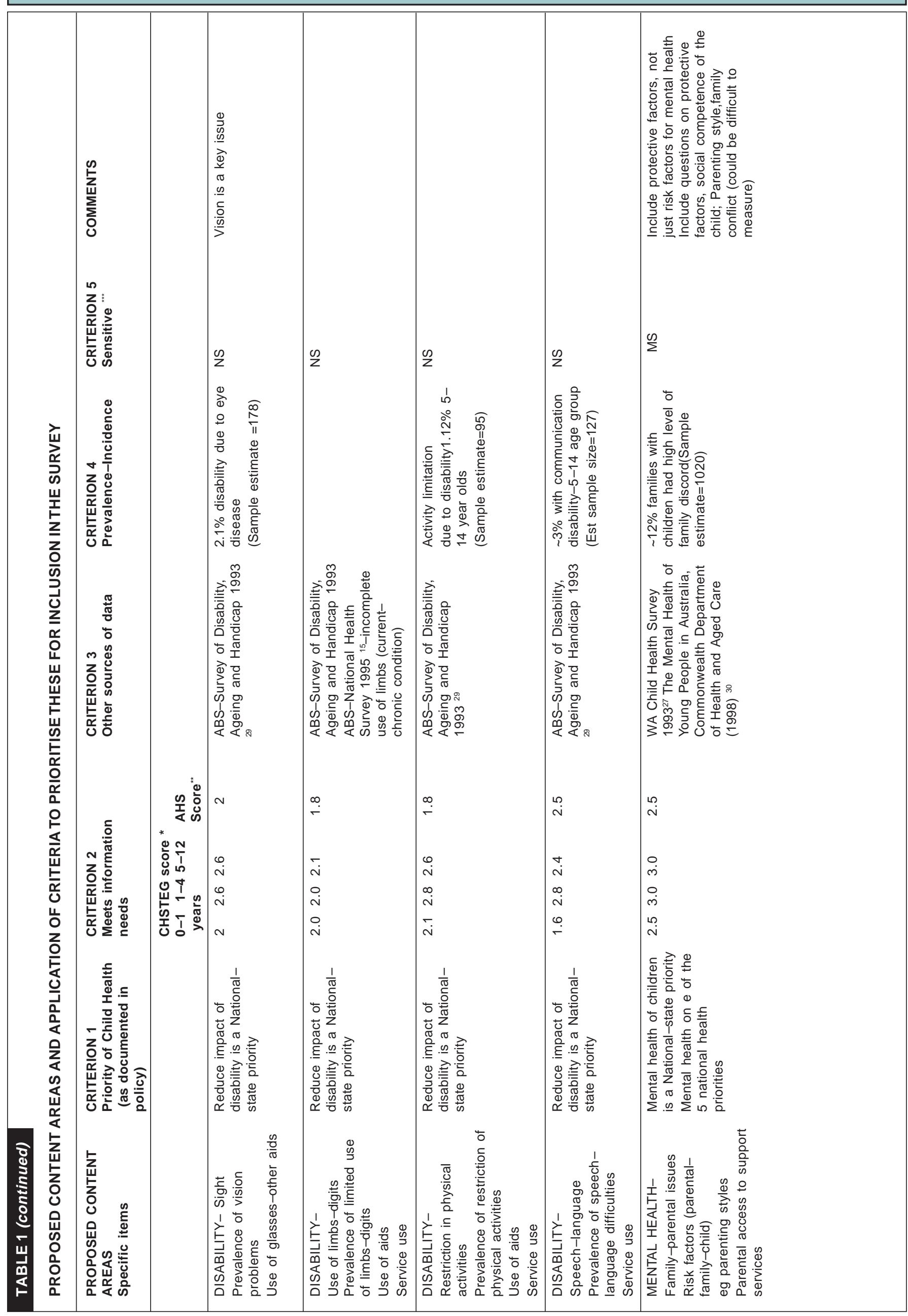




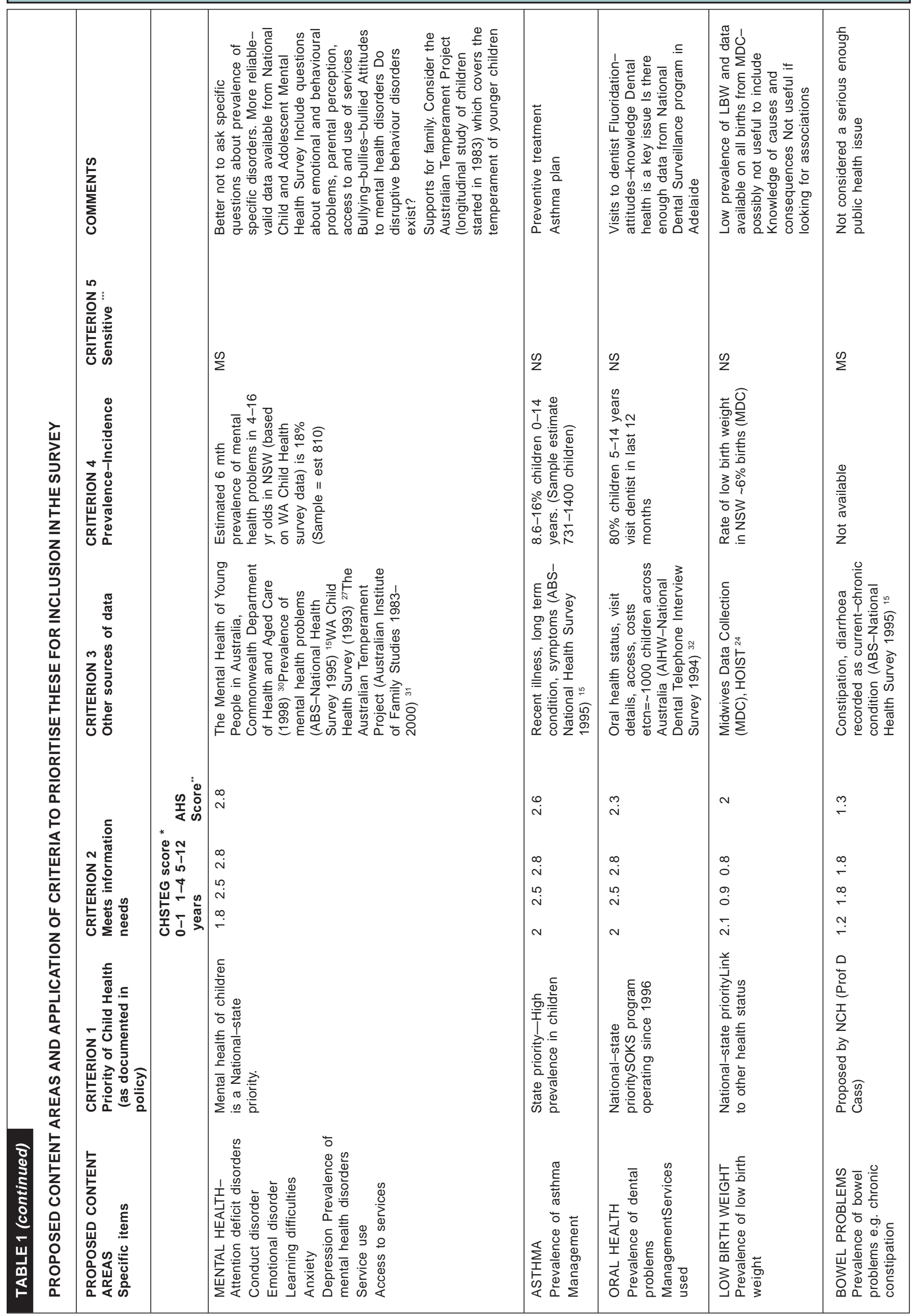




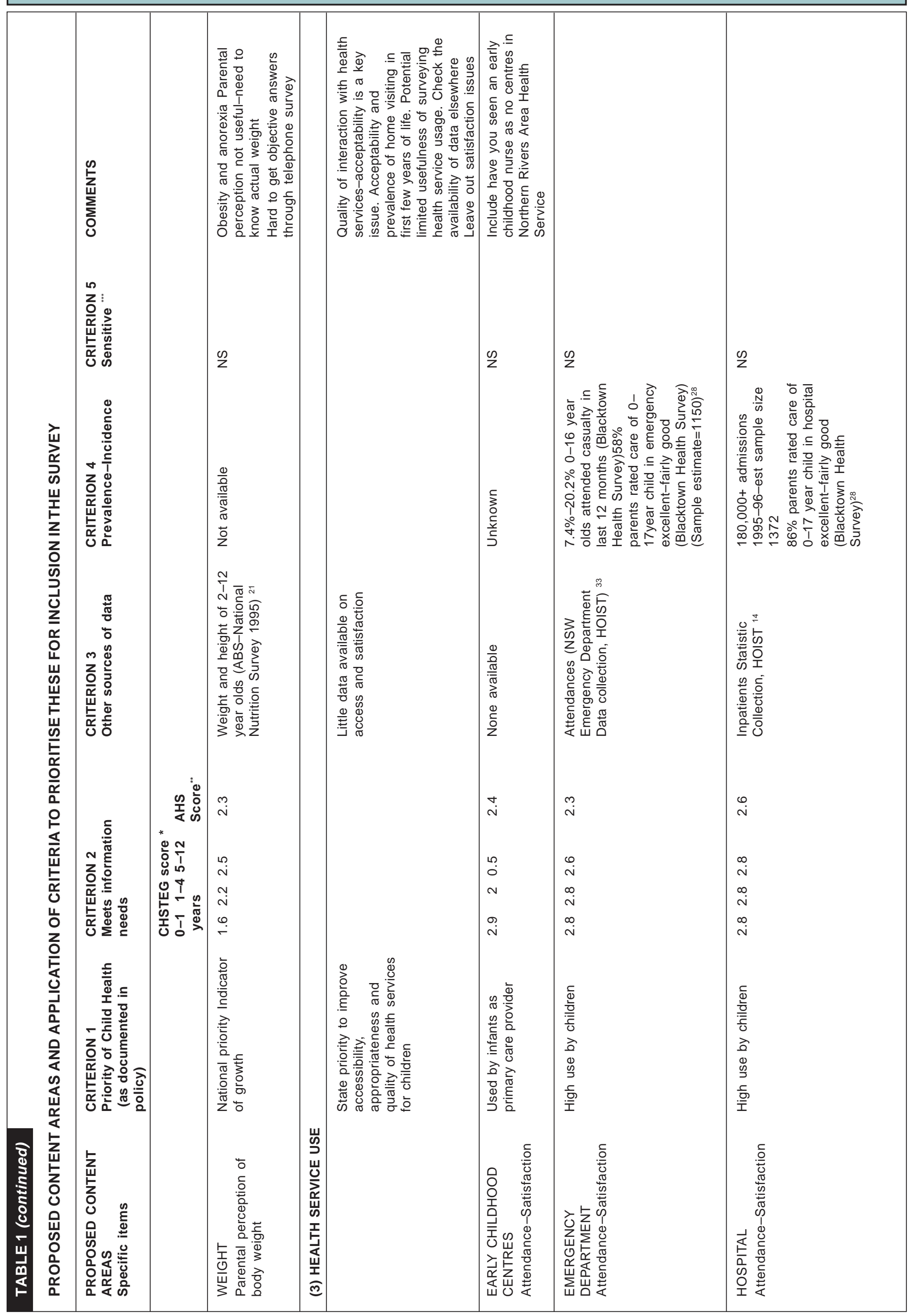




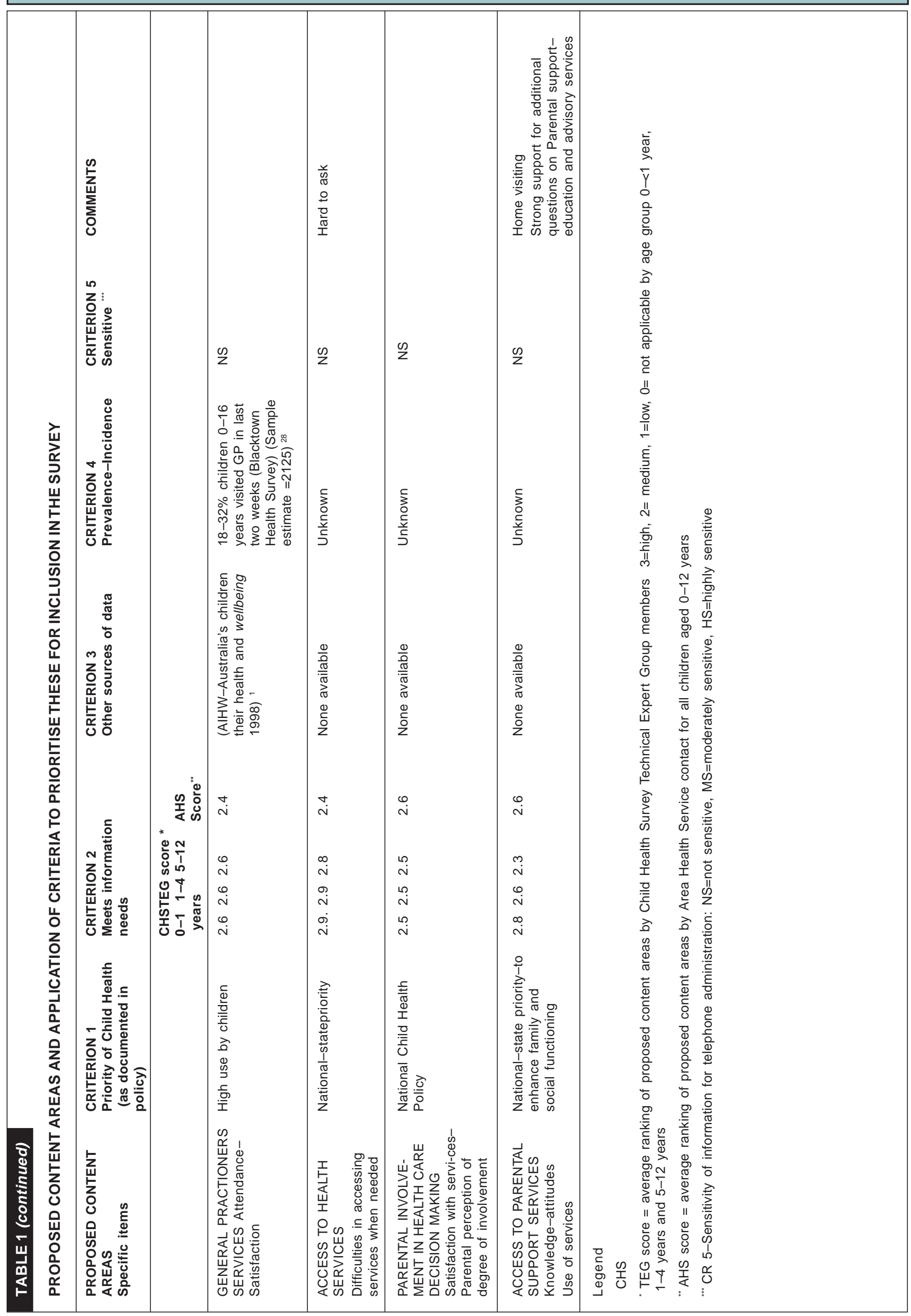


Final list of content areas and proposed measurement elements

Following the application of the agreed criteria, the list of proposed content areas was considered for the final survey, with some content areas being dropped and others modified (Table 2). Content areas that were dropped included lead exposure, burns and scalds, motor vehicle accidents, attendance at antenatal care and birthweight (available through another data collection), ${ }^{24}$ parental alcohol intake, bowel problems, weight, and parental involvement in healthcare decision-making. Parental and family interaction and family function was limited to the specific components reflecting information needs and available measurement tools such as the McMaster Family Assessment Device, ${ }^{34}$ and mental health was limited to the components available using The Child Health Questionnaire. ${ }^{35}$ Once the content areas were agreed, the CHSTEG was consulted on proposed measurement elements, which are outlined in Table 2. The proposed measurement elements were used as the basis for development of questions. 
TABLE 2

\section{PROPOSED CONTENT AREAS FOR INCLUSION INTHE CHILD HEALTH SURVEY AND PROPOSED} MEASUREMENT ELEMENTS

\begin{tabular}{|c|c|c|}
\hline Age (years) & Content Area & Proposed Measurement Elements \\
\hline \multicolumn{3}{|c|}{ Risk-protective factors for health and disease } \\
\hline $0-<1$ & Nutrition-Breastfeeding & $\begin{array}{l}\text { Prevalence; Provision of breastfeeding spaces in public; Attitudes to } \\
\text { breastfeeding in public }\end{array}$ \\
\hline $0-<1$ & Nutrition-Folate & $\begin{array}{l}\text { Use of folate supplementation prior to conception and during } \\
\text { pregnancy }\end{array}$ \\
\hline $0-<1$ & $\begin{array}{l}\text { Sudden Infant Death } \\
\text { Syndrome (SIDS) }\end{array}$ & Sleeping position \\
\hline $0-4$ & Drowning & $\begin{array}{l}\text { Place of near drowning incidents; Fenced child play areas } \\
\text { (rural); Attendance at learn to swim classes }\end{array}$ \\
\hline $0-4$ & Burns and scalds & $\begin{array}{l}\text { Awareness of prevention methods; Treatment of burns and scalds } \\
\text { that don't reach hospital; How burn sustained }\end{array}$ \\
\hline $0-4$ & $\begin{array}{l}\text { Feeding and other child-rearing } \\
\text { difficulties }\end{array}$ & Prevalence; Service use and satisfaction \\
\hline $0-4$ & Immunisation & $\begin{array}{l}\text { Barriers-access to immunisation; Attitudes to immunisation; Service } \\
\text { use; Status at school age }\end{array}$ \\
\hline $0-4$ & Cigarette smoke exposure & Smoke free households; Parental smoking \\
\hline $0-12$ & Sun exposure & Preventive measures used; Frequency of use of preventive measures \\
\hline $0-12$ & Nutrition-Food intake & Fruit and vegetable intake; Takeaway food intake \\
\hline $0-12$ & Nutrition-Food security & Prevalence of insufficient money to buy food \\
\hline $1-12$ & Physical inactivity & Hours of TV watching \\
\hline $0-12$ & $\begin{array}{l}\text { Parent-child-family } \\
\text { interaction-mental health }\end{array}$ & $\begin{array}{l}\text { Parenting style; Enjoyment and satisfaction with parenting, } \\
\text { perception of competence; Parental conflict; Family conflict; Child's } \\
\text { social competence }\end{array}$ \\
\hline $0-12$ & Social capital & $\begin{array}{l}\text { Connectedness to community; Trust in community; Perceptions of } \\
\text { community }\end{array}$ \\
\hline $5-12$ & Injury-Contact sports & $\begin{array}{l}\text { Preventive measures eg. use of protective gear; Parental perception } \\
\text { of safety of sports; Actions parents take to reduce risk-injury }\end{array}$ \\
\hline $5-12$ & Physical activity & Parental concern re safety and walking to school \\
\hline $5-12$ & Smoking & Parental action and attitudes to child smoking \\
\hline \multicolumn{3}{|c|}{ Health status } \\
\hline $0-12$ & Health status & $\begin{array}{l}\text { General measure of health status e.g. Child Health Questionnaire } \\
(\mathrm{CHQ})^{35}\end{array}$ \\
\hline $0-12$ & Disability & $\begin{array}{l}\text { Prevalence of disability; Type of disability; Access to and use of } \\
\text { services }\end{array}$ \\
\hline $2-12$ & Asthma & Prevalence; Management \\
\hline $0-12$ & Dental health & Service use \\
\hline \multicolumn{3}{|c|}{ Health service use and satisfaction } \\
\hline $0-12$ & Health service use & $\begin{array}{l}\text { Services used-accessed in response to specific health problems } \\
\text { Satisfaction with services used (tie in with feeding-other infant } \\
\text { problems); Acceptance of homevisiting }\end{array}$ \\
\hline $0-12$ & Access to parental support services & $\begin{array}{l}\text { Use of parental support services; Types of support used (not just } \\
\text { health); Difficulties accessing services }\end{array}$ \\
\hline $0-12$ & $\begin{array}{l}\text { Parental involvement in health care } \\
\text { decision making }\end{array}$ & $\begin{array}{l}\text { Parental perception about degree of involvement in } \\
\text { health care decision making }\end{array}$ \\
\hline \multicolumn{3}{|l|}{ Demography } \\
\hline $0-12$ & Parent factors & $\begin{array}{l}\text { Age, education, employment, receipt of benefits, place of birth, when } \\
\text { arrived in Australian; Aboriginal-Torres Strait Islander origin }\end{array}$ \\
\hline $0-12$ & Child factors & $\begin{array}{l}\text { Age, place of birth, country of birth, education, childcare; preschool, } \\
\text { play group attendance, receipt pension-benefits, adopted-fostered, } \\
\text { carers }\end{array}$ \\
\hline $0-12$ & Household factors & $\begin{array}{l}\text { Family structure, number of children in house, housing type, suburb, } \\
\text { postcode, health insurance status }\end{array}$ \\
\hline
\end{tabular}




\section{Question development}

\section{Question Inclusion Criteria}

After the content areas and measurement elements were decided, the next step in survey development was consideration of questions to address these. The CHSTEG developed criteria to determine which questions should be included. To be included, the question had to:

- provide the most important and useful information on the content area;

- be suitable for telephone administration;

- be reliable when reported by proxy respondent.

Identification and review of existing surveys for possible questions

In order to determine which questions might be included, any previous surveys that included questions considered relevant to the proposed content areas were identified. The search for existing surveys was not limited to surveys of children; many surveys targeted at adults were also reviewed where content areas included those relevant to the New South Wales Child Health Survey. The method of delivery of each survey was also noted, as questions delivered by one method, for example face-to-face, would possibly require modification for telephone delivery.

Over 40 surveys were found and reviewed for suitable questions. Surveys that ultimately provided questions for the New South Wales Child Health Survey are listed in Table 3 .

\section{Use of existing questions}

A set of available questions for each specific element of content areas was developed from existing national, state or international surveys, where questions were available. As much as possible questions were used exactly as they were cited in the source surveys. Questions pertaining to specific survey instruments or questions scales were used exactly according to the validated instrument: for example, the McMaster Family Assessment Device, ${ }^{15}$ and The Child Health Questionnaire. ${ }^{35}$

\section{Modification of questions}

If the mode of administration of the source question was by face-to-face interview or self-complete questionnaire, the questions were modified if necessary to develop 


\section{TABLE 3}

\section{SURVEYS IDENTIFIED AND REVIEWED FOR POSSIBLE QUESTIONS}

\begin{tabular}{|c|c|}
\hline Name of Survey & Administration \\
\hline \multicolumn{2}{|l|}{ National surveys } \\
\hline National Health Survey, $1995{ }^{15}$ & $\begin{array}{l}\text { Proxy interview of parent for questions related to children } \\
\text { by parent; face-to-face household interview. Breastfeeding } \\
\text { questions asked of children aged 0-3 years; sun protection } \\
\text { questions asked of all children. }\end{array}$ \\
\hline Child Immunisation Questionnaire, 199519 & $\begin{array}{l}\text { Face-to-face interview of parent of child aged } 0-14 \text { years } \\
\text { about health service use, sight and hearing, dentist and } \\
\text { childcare }\end{array}$ \\
\hline $\begin{array}{l}\text { Australian School Students Alcohol and } \\
\text { Drugs Survey (ASSAD), } 1996^{26}\end{array}$ & $\begin{array}{l}\text { Self-completed questionnaire by children aged } 12-17 \text { years } \\
\text { currently attending school }\end{array}$ \\
\hline
\end{tabular}

National Nutrition Survey, 199521

Face-to-face household interview

Source

Australian Bureau of Statistics

Australian Bureau of Statistics

\section{Center for}

Behavioural Research

in Cancer, Anti-

Cancer Council of

Victoria, November

1998

Australian Bureau of

Statistics and

Commonwealth

Department of Health

and Family Services

CSIRO Food and

Nutrition, Adelaide SA

Commonwealth

4500 children aged 4-17 years face-to-face interviews of randomly selected household, parent completed for children 4-17 years and also self-completde for children aged 13-17 years

National Dental Telephone Interview Telephone survey

Department of Health and Aged Care

Australian Institute of Health and Welfare

Dental Statistics and Research Unit

\section{State surveys}

ANZFA Eat Well Tasmania, 1995-1999 ${ }^{37} \quad$ Telephone survey

\section{Quit Evaluation Studies $1998^{38}$}

The Western Australian Pregnancy and Infancy Survey 1995

The Research Study of Birth Defects Part 1 Pregnancy Questionnaire 1997-2000 40

The Western Australian Child Health Survey, 199327

Determinants of initiation and duration of breastfeeding $1998{ }^{41}$

NSW Schools and Physical Activity Survey, $1997^{23}$

NSW Health Surveys, 1997 and $1998^{22}$
Face to face interviews in households including 2500 adults in each wave

Survey of mothers 12 weeks post birth of child; Self completed, paper based.

Self completed questionnaire by women who recently had a baby

A number of survey instruments:Child Health Questionnaire - Survey of all children in household aged 4-16 years face to face interview with parent-carer

Family Health and Activity Questionnaire -information about family relationships of selected households self completed by primary respondent to Child Health Questionnaire Family Dwelling Questionnaire-interviewer collected information on dwelling

Household Record Form-information on the demographic data of all household members and their relationships to each respondent (principle caregiver)-Collected by face-to-face interview

Family Background Questionnaire-education, employment and other ABS standard demographic data of parent (major care giver) and partner (other major care giver)Collected by face-to-face interview

Cohort study of 556 Perth women-self-completed questionnaire

Targeted children-youth in Year 8-Year 10 while at school with self-completed questionnaire

Telephone survey of people aged 16 years and over
Menzies Centre for Population Research, University of Tasmania Trotter and Mullins, Quit Victoria

Telethon Institute for Child Health Research Telethon Institute for Child Health Research

Australian Bureau of Statistics and Institute of Child Health, University of Western Australia

Jane A Scott,

University of

Western Australia

Department of Public

Health and

Community Medicine, University of Sydney

Health Survey

Program, NSW

Department of Health 
TABLE 3 (continued)

\section{SURVEYS IDENTIFIED AND REVIEWED FOR POSSIBLE QUESTIONS}

\begin{tabular}{|c|c|}
\hline Name of Survey & Administration \\
\hline $\begin{array}{l}\text { NSW Skin Protection Survey-'Seymour } \\
\text { the Snowman', } 199842\end{array}$ & $\begin{array}{l}\text { Telephone survey with proxy completion by carers of } \\
\text { children aged } 0-12 \text { years }\end{array}$ \\
\hline NSW Youth Sports Injury Survey 1994-95 43 & $\begin{array}{l}\text { School-based survey of children-youth years } 7-11 \text {, } \\
\text { self-completed questionnaire }\end{array}$ \\
\hline Holroyd Health Survey, $1995^{44}$ & $\begin{array}{l}\text { Child Health Questionnaire-proxy completion over the } \\
\text { telephone by parent }\end{array}$ \\
\hline $\begin{array}{l}\text { Baby Health Questionnaire, } 1989 \\
\text { (NSAHS) } 45\end{array}$ & $\begin{array}{l}\text { Parents of normal full-term infants aged six months; } \\
\text { self-completed mailed questionnaire }\end{array}$ \\
\hline Blacktown Health Survey, 199328 & $\begin{array}{l}\text { Child Health Questionnaire proxy completion over the } \\
\text { telephone by parent of children aged } 0-17 \text { years }\end{array}$ \\
\hline Social capital survey in five NSW & Self-completed paper based survey \\
\hline
\end{tabular}

communities, 199746

Personal Health Record ('Blue Book')

Survey, $1992^{47}$

Smoking among School Students in

Central and South Western Sydney, $1998{ }^{48}$

Pnuemococcal Survey, $1998^{49}$

South Australian Health Goals and

Targets Health Priority Areas Survey 199850

South Australian Northern Services

Planning Unit Survey $1996{ }^{51}$

South Australian SERCIS Survey On

Disability Prevalence (1996) ${ }^{52}$

South Australian Health Omnibus Survey

(Autumn 1995) ${ }^{53}$

South Australian Health Omnibus Survey

(Spring 1995) ${ }^{54}$

Queensland Public Health and Media

Reach Survey, 199755

Queensland Public Health and Media

Reach Survey, $1996{ }^{56}$

\section{International surveys}

National Longitudinal Survey of Children,

Canada, 199357

USDA children's food security scale

1995-1999 58

SF36 59

CHQ-PF28 ${ }^{35}$

McMaster Family Assessment Device $19933^{34}$
Face to face interview of parents of children aged $0-4$ years

Self-completed questionnaire of year 10 and 11 students

Telephone survey of parent proxies

Telephone survey of adults aged 18 years and over

Telephone survey of adults aged 18 years and over

Telephone survey of adults aged 18 years and over of themselves and collected information on other household members by proxy.

Telephone survey of adults aged 15 years and over. Some questions of children asked if respondent was a parent.

Telephone survey of adults aged 15 years and over. Some questions of children asked of proxy respondent

Telephone-based survey. Questions asked of parents about children under five years of age

Telephone-based survey. Questions asked of parents about children aged 12 years or under

A number of survey instruments:Household contact

GeneralQuestionnaire

Parent Questionnaire

Children's Questionnaire

All surveys completed by proxy, about selected child from household in face-to-face interview in the respondents'

home

Household food security survey (households with at least one child aged 0-17 years). Administered annually with the Census Bureau's Current Population Survey.

Self-rating of health

Parents rating of child's health and emotional and physical wellbeing, PF50 previously conducted by self-complete questionnaire through schools

A questionnaire about family functioning used in the WA Child Health Survey 1993. ${ }^{27}$ The tool generates a score between 1 and 4 , with 1 reflecting healthy family functioning and 4 reflecting unhealthy functioning (eg. avoiding fears, having lots of bad feelings within the family)
Source

NSW Department of

Health and NSW

Cancer Council

Northern Sydney Area

Health Service

Western Sydney Area

Health Service

Wentworth Area

Health Service

Western Sydney Area

Health Service

Onyx and Bullen,

1997

NSW Department of

Health

Chris Rissel, Central Sydney Area Health Service

Peter Mclntyre, New Children's Hospital,

Westmead

South Australian

Health Commission

South Australian

Health Commission

South Australian

Health Commission

South Australian

Health Commission

South Australian

Health Commission

Queensland

Department of Health

Queensland

Department of Health

Canadian Department of Justice

Economic research

service, US

Department of Agriculture (USDA)

Ware, Snow, Kosinski, Gandek. SF-36 Health

Survey Manual and Interpretation Guide 1993

Langraf, Abetz and Ware. The Child

Health Questionnaire (CHQ) User's Manual, 1996

Epstein N B, Baldwin LM and Bishop DS

The McMaster Family Assessment Device, 1983 
suitable wording for telephone administration. Questions developed overseas were also modified to read in simple Australian English where possible (Table 4).

When questions were taken from adult surveys, they needed to be modified to be applicable to children or the environment that children live in (Table 5). The question also needed to be appropriate to ask of parents on behalf of children.

There was concern that some questions would require recall of more than 12 months by proxy respondent, which could result in recall bias. As a result, questions were restricted to recall in the last 12 months, which influenced

\section{TABLE 4}

\section{EXAMPLES OF QUESTION MODIFICATION INTO AUSTRALIAN ENGLISH}

\begin{tabular}{|c|c|c|}
\hline $\begin{array}{l}\text { Proposed questions for use in } \\
\text { child health survey }\end{array}$ & $\begin{array}{l}\text { Original question and/or source } \\
\text { of question }\end{array}$ & Comments-use of data \\
\hline $\begin{array}{l}\text { What type of school does [child] } \\
\text { currently attend? } \\
\text { (READ OPTIONS 1-6 SINGLE } \\
\text { RESPONSE) } \\
\text { 1. Public school } \\
\text { 2. Catholic school } \\
\text { 3. Independent school } \\
\text { 4. Special education school } \\
\text { 5. School of the Air } \\
\text { 6. Any other school (Specify) } \\
\text { 7. Don't know } \\
\text { 8. Refusal }\end{array}$ & $\begin{array}{l}\text { What type of school is [child] currently } \\
\text { in? } \\
\text { (READ OPTIONS, SINGLE } \\
\text { RESPONSE) } \\
\text { 1. Public school } \\
\text { 2. Catholic school, publicly funded } \\
\text { 3. Private school } \\
\text { 4. Other } \\
\text { 5. Don't know } \\
\text { 6. Refusal } \\
\text { Source: National Longitudinal Survey } \\
\text { of Children, Canada } 199357\end{array}$ & $\begin{array}{l}\text { - Making the categories } \\
\text { appropriate to Australian } \\
\text { responses }\end{array}$ \\
\hline $\begin{array}{l}\text { The next questions are about } \\
\text { preschool } \\
\text { Has [child] ever attended preschool? } \\
\text { (PROMPT: PRESCHOOL IS USUALLY } \\
\text { ATTENDED FOR A FEW HOURS } 3 \text { TO } \\
\text { 4 TIMES A WEEK BEFORE A CHILD } \\
\text { STARTS FULL-TIME SCHOOL) } \\
\text { 1. Yes } \\
\text { 2. No } \rightarrow \text { next section } \\
\text { 3. Don't know } \rightarrow \text { next section } \\
\text { 4. Refused } \rightarrow \text { next section }\end{array}$ & $\begin{array}{l}\text { Did he-she attend junior kindergarten? } \\
\text { 1. Yes } \\
\text { 2. No } \\
\text { 3. Don't know } \\
\text { 4. Refused } \\
\text { Source: National Longitudinal Survey } \\
\text { of Children, Canada } 199357\end{array}$ & $\begin{array}{l}\text { - Change from junior } \\
\text { kindergarten in Canada to } \\
\text { preschool in Australia }\end{array}$ \\
\hline
\end{tabular}

\section{TABLE 5}

\section{EXAMPLES OF ADULT QUESTION MODIFICATION FOR ADMINISTRATION IN A CHILD HEALTH SURVEY}

\begin{tabular}{|c|c|c|}
\hline $\begin{array}{l}\text { Proposed questions for use in } \\
\text { child health survey }\end{array}$ & $\begin{array}{l}\text { Original question and/or source } \\
\text { of question }\end{array}$ & Comments-use of data \\
\hline $\begin{array}{l}\text { The following questions are about } \\
\text { tobacco smoking. This includes } \\
\text { cigarettes, cigars and pipes. } \\
\text { Which of the following best describes } \\
\text { your household? } \\
\text { (MULTIPLE RESPONSE: READ OUT) } \\
\text { 1. Myself and others in this } \\
\text { 2. I smoke, but no one else does } \\
\text { 3. I don't smoke, but others in the } \\
\text { 4. Nousehold do } \\
\text { No-one in the household smokes } \\
\text { 5. Don't know } \rightarrow \text { SM5 } \\
\text { 6. Refused } \rightarrow \text { SM5 }\end{array}$ & $\begin{array}{l}\text { Which of the following best describes } \\
\text { your smoking status? } \\
\text { 1. I smoke daily } \\
\text { 2. I smoke occasionally } \\
\text { 3. I don't smoke now but I used to } \\
\text { 4. I've tried it a few times but never } \\
\text { smoked regularly } \\
\text { 6. I've never smoked } \\
\text { Source: NSW Health Survey, } 1997 \\
\text { 1998 }\end{array}$ & $\begin{array}{l}\text { - Changing from individual } \\
\text { smoking status to } \\
\text { household smoking } \\
\text { environment }\end{array}$ \\
\hline
\end{tabular}




\section{TABLE 6}

\section{EXAMPLES OF NEWLY DEVELOPED QUESTIONS}

Proposed questions for use in child health survey

The next few questions are about food. I'm going to read you a list of different food and drinks. Please tell me how much of these foods and drinks [child] usually consumes per day or per week.

How many serves of fruit does [child] usually eat in a day, including fresh, canned and dried fruit? 1 serve $=1 / 2$ piece fruit, $1 / 3$ cup canned fruit, 1 tablespoon of dried fruit

1. __ serves per day

2. serves per week

3. Doesn't eat fruit

4. Don't know

5. Refused

How many serves of salads or raw vegetables does [child] usually eat in a day? 1 serve $=1 / 4$ cup salad or 4 vegetable sticks

1. ___ serves per day

2. serves per week

3. Doesn't eat salads or raw vegetables

4. Don't know

5. Refused

\section{Comments-use of data}

Questions are newly derived as there are limited questions suitable for use in children-further investigation of possible question sources is ongoing.

Fruit and vegetable intake is important problem in children's nutrition as highlighted by ABS National Nutrition Survey $1995^{21}$ and others.

Quantity of fruit and vegetables eaten will depend on serving sizes that are age specific and difficult to determine in children. Including a variety of fruits and vegetables is important. Nutrition experts considered frequency i.e.number of times fruit and vegetables are eaten in the day-week an important indicator than quantity. Vegetables are separated out to ensure all vegetable sources are included.

Data will be analysed in two groups according to hours in childcare for younger children. the type of questions asked about maternal folate intake in pregnancy and sleeping position of younger children.

\section{Development of new questions}

When no suitable questions were available, new questions needed to be developed (Table 6). In developing new questions, the indicator to be measured was defined and relevant topic experts were consulted. New questions were drafted by the survey team and fed back to the relevant experts for consideration. All new questions were considered and approved by the CHSTEG. Sixty-five questions were new as no source of current question could be identified. Some content areas were excluded at this point as suitable questions could not be identified or developed.

\section{Application of question inclusion criteria}

The question inclusion criteria were then applied to the list of proposed questions. In terms of providing the most important and useful information on the content area, questions on dental health focused on service use as very little statewide data was available on attendance at dental professionals by children. The level of physical activity of children was not included as parents or carers would be unreliable as a source of this data. Instead, it was decided to ask about physical inactivity through hours of TV watchin and playing video games, which could be more reliably reported.

\section{Review of all questions and piloting of draft survey instrument}

The NSW Health Survey Program staff checked that all questions had a single concept, simple English, clear meaning, and adequate response frames (Table 7).

Two pilots of the draft survey instrument were then carried out in the CATI facility to review questions as well as test specific methodological issues. Piloting involved asking the questionnaire of a simple random sample of the population, with 240 respondents in the first pilot and 251 in the second. This process allowed staff to assess the order and timing of questions, use of questions to select the proxy respondent and the age and sex distribution of the respondents. This process allowed revision to 


\section{TABLE 7}

\section{EXAMPLES OF QUESTION MODIFICATIONTO IMPROVE CLARITY}

\begin{tabular}{|c|c|c|}
\hline $\begin{array}{l}\text { Proposed questions for use in } \\
\text { child health survey }\end{array}$ & $\begin{array}{l}\text { Original question and/or source } \\
\text { of question }\end{array}$ & Comments-use of data \\
\hline $\begin{array}{l}\text { Have you ever clearly told [child] not to } \\
\text { smoke or forbidden [him/her] from } \\
\text { smoking? } \\
\text { 1. Yes } \\
\text { 2. No } \\
\text { 3. Don't know } \\
\text { 4. Refused }\end{array}$ & $\begin{array}{l}\text { Does your family have clear rules } \\
\text { about smoking? } \\
\text { 1. Yes } \\
2 \text {. No } \\
\text { Source: Smoking among school } \\
\text { students in Central and South West } \\
\text { Sydney Area Health Services, } 1998{ }^{48}\end{array}$ & $\begin{array}{l}\text { Work by Rissel et al }{ }^{38} \text { in } \\
\text { adolescent school children } \\
\text { indicated that clear rules } \\
\text { about smoking was related } \\
\text { to lower smoking rates }\end{array}$ \\
\hline $\begin{array}{l}\text { Thinking back to before you were } \\
\text { pregnant with [child] were you planning } \\
\text { to become pregnant? } \\
\text { 1. Yes-trying to become pregnant } \\
\text { 2. Not trying to become pregnant } \\
\text { 3. Sort of-not actively trying to } \\
\text { avoid pregnancy } \\
\text { 4. Not applicable-respondent not } \\
\text { birth mother of [child] 5. Don't } \\
\text { know }\end{array}$ & $\begin{array}{l}\text { Before you became pregnant with } \\
\text { your recent pregnancy, for how long } \\
\text { were you trying to become pregnant? } \\
\text { 1. Months } \\
\text { 2. Years } \\
\text { 3. Not specifically trying to become } \\
\text { pregnant } \\
\text { Source: The Western Australian } \\
\text { Pregnancy and Infancy Survey, } \\
\text { 199539 }\end{array}$ & $\begin{array}{l}\text { To prevent spina bifida } \\
\text { folate should be taken } \\
\text { periconceptually. Identifies } \\
\text { number of pregnancies for } \\
\text { denominator of proportion } \\
\text { of women of children aged } \\
0-12 \text { months taking folate } \\
\text { prior to pregnancy. }\end{array}$ \\
\hline $\begin{array}{l}\text { As far as you know, does [child] have } \\
\text { normal vision in both eyes? } \\
\text { 1. Yes } \\
\text { 2. No } \\
\text { 3. Don't know } \\
\text { 4. Refused }\end{array}$ & $\begin{array}{l}\text { Does [child] have normal vision in } \\
\text { both eyes? } \\
\text { 1. Yes } \rightarrow \text { next section } \\
\text { 2. No } \\
\text { 3. Don't know } \\
\text { Source: WA Child Health Survey } \\
1993^{27}\end{array}$ & $\begin{array}{l}\text { - Proportion of children aged } \\
2-12 \text { years with normal } \\
\text { vision }\end{array}$ \\
\hline
\end{tabular}

questions to ensure their acceptability and accuracy when used over the telephone.

\section{Summary of question development}

Table 8 lists each of the content areas planned to be included in the New South Wales Child Health Survey 2001; the number of questions to be included; the age group for which the questions would be asked; the specific elements of the content area that the questions addressed; the main source of the questions; and whether the question was sourced from another survey, modified, or developed as a new question when no source question was available.

In total, 352 questions were proposed to the CHSTEG. The final survey included 285 questions covering 34 different topic areas. 
TABLE 8

SUMMARY OF QUESTION DEVELOPMENT FOR THE SURVEY INSTRUMENT, NEW SOUTH WALES CHILD HEALTH SURVEY 2001: QUESTION ORIGIN,TARGET AGE GROUP AND METHOD OF DEVELOPMENT

\begin{tabular}{|c|c|c|c|c|}
\hline $\begin{array}{l}\text { Content area } \\
\text { (number of questions) }\end{array}$ & Age group & $\begin{array}{l}\text { Specific measurement } \\
\text { elements }\end{array}$ & Source of questions & Method of development \\
\hline $\begin{array}{l}\text { Health service use-early } \\
\text { childhood health centre (5) }\end{array}$ & $0-4$ years & $\begin{array}{l}\text { Attendance at, reason not } \\
\text { attending }\end{array}$ & $\begin{array}{l}\text { ABS Child Immunisation } \\
\text { Questionnaire } 1995^{19} \\
\text { New questions }\end{array}$ & $\begin{array}{l}\text { Modified from source } \\
\text { questions and new } \\
\text { questions developed }\end{array}$ \\
\hline $\begin{array}{l}\text { Health service use-GPs, } \\
\text { services attended, } \\
\text { emergency department (4) }\end{array}$ & $0-12$ years & $\begin{array}{l}\text { Place doctor consulted, } \\
\text { services attended, } \\
\text { emergency department } \\
\text { attended }\end{array}$ & $\begin{array}{l}\text { Holroyd Child Health } \\
\text { Survey } 1995^{44} ; \text { WA Child } \\
\text { Health Survey } 1993^{27} ; \\
\text { New questions }\end{array}$ & $\begin{array}{l}\text { Modified from source } \\
\text { questions and new } \\
\text { questions developed }\end{array}$ \\
\hline $\begin{array}{l}\text { Personal health records } \\
\text { (3) }\end{array}$ & $0-11$ years & $\begin{array}{l}\text { Use of personal health } \\
\text { record }\end{array}$ & New questions & $\begin{array}{l}\text { Existing surveys } \\
\text { reviewed-ABS } \\
\text { Immunisation and NSW } \\
\text { Personal Health Record } \\
\text { Survey however } \\
\text { questions were } \\
\text { unsutiable and new } \\
\text { questions were } \\
\text { developed }\end{array}$ \\
\hline Folate in pregnancy (8) & $\begin{array}{l}0-11 \text { months, } \\
\text { respondent is } \\
\text { mother }\end{array}$ & $\begin{array}{l}\text { Planned pregnancy, use } \\
\text { of folate, reason for use, } \\
\text { knowledge re need to use } \\
\text { folate in pregnancy }\end{array}$ & $\begin{array}{l}\text { Western Australian } \\
\text { Pregnancy and Infancy } \\
\text { Survey, } 1995^{39} \text {;Western } \\
\text { Australian Research } \\
\text { Study of Birth Defects } \\
\text { Part } 1 \text { Pregnancy } \\
\text { Questionnaire 1997- } \\
2000^{40} \text {;ANZFA Eat Well } \\
\text { Tasmania Survey 1995- } \\
1999^{37} \text {;CSIRO, National } \\
\text { Nutrition Survey } 1993^{36}\end{array}$ & $\begin{array}{l}\text { Questions modified from } \\
\text { existing surveys and } \\
\text { consultation with experts }\end{array}$ \\
\hline Sleeping position (1) & $0-11$ months & $\begin{array}{l}\text { Position baby slept in from } \\
\text { birth }\end{array}$ & $\begin{array}{l}\text { Western Australian } \\
\text { Pregnancy and Infancy } \\
\text { Survey, } 1995^{39}\end{array}$ & $\begin{array}{l}\text { Question used from } \\
\text { source without } \\
\text { modification }\end{array}$ \\
\hline Breastfeeding (14) & $\begin{array}{l}0-23 \text { months and } \\
\text { respondent is } \\
\text { mother or father }\end{array}$ & $\begin{array}{l}\text { Ever-current breastfed, } \\
\text { use of infant formula, } \\
\text { cow's milk, other milks, } \\
\text { age of introduction of } \\
\text { solids, total time } \\
\text { breastfed, reasons } \\
\text { breastfed }\end{array}$ & $\begin{array}{l}\text { ABS National Health } \\
\text { Survey, } 1995{ }^{15} \text {; Scott } \\
\text { JA, Determinants of } \\
\text { initiation and duration of } \\
\text { breastfeeding }{ }^{41} \text { (PhD } \\
\text { thesis) }\end{array}$ & $\begin{array}{l}\text { Consultation with } \\
\text { nutrition experts. } \\
\text { Questions used from } \\
\text { source without } \\
\text { modification, one } \\
\text { question modified }\end{array}$ \\
\hline Nutrition (7) & $2-12$ years & $\begin{array}{l}\text { Intake of fruit, vegetables, } \\
\text { milk, soft drink and fruit } \\
\text { juice }\end{array}$ & New questions & $\begin{array}{l}\text { Consultation with } \\
\text { nutrition experts and } \\
\text { questions newly } \\
\text { developed }\end{array}$ \\
\hline Food security (8) & $0-12$ years & $\begin{array}{l}\text { Times ran out of food, } \\
\text { action taken if no food, } \\
\text { prevalence of child(ren) } \\
\text { hungry }\end{array}$ & $\begin{array}{l}\text { ABS National Nutrition } \\
\text { survey } 1995^{21} \text {; USDA } \\
\text { Children's food security } \\
\text { scale } 1995-1999^{58} \text {, } \\
\text { National Longitudinal } \\
\text { Survey of children, } \\
\text { Canada } 1993^{57}\end{array}$ & $\begin{array}{l}\text { Consultation with } \\
\text { nutrition experts; some } \\
\text { modification from } \\
\text { sources }\end{array}$ \\
\hline Immunisation (3) & $\begin{array}{l}2 \text { months }-4 \\
\text { years }\end{array}$ & $\begin{array}{l}\text { Places vaccinated, views } \\
\text { of vaccination, influences } \\
\text { on views }\end{array}$ & $\begin{array}{l}\text { Queensland Public } \\
\text { Health and Media Reach } \\
\text { Survey } 1996{ }^{56} \text {; ABS } \\
\text { Child Immunisation, } \\
199519\end{array}$ & $\begin{array}{l}\text { Consultation; } \\
\text { modification from source }\end{array}$ \\
\hline Asthma (14) & $2-12$ years & $\begin{array}{l}\text { Ever asthma, symptoms, } \\
\text { GP and hospital } \\
\text { attendance, effect on } \\
\text { activity and sleep, use of } \\
\text { medication }\end{array}$ & $\begin{array}{l}\text { NSW Health Survey } \\
1997-1998{ }^{22}\end{array}$ & $\begin{array}{l}\text { Consultation with NSW } \\
\text { Health Asthma Expert } \\
\text { group; modification from } \\
\text { source }\end{array}$ \\
\hline Dental (8) & $1-12$ years & $\begin{array}{l}\text { Use of dental services, } \\
\text { SOKS assessment, visit } \\
\text { private dental when } \\
\text { eligible for public dental, } \\
\text { treatment received }\end{array}$ & $\begin{array}{l}\text { National Dental } \\
\text { Telephone Interview } \\
\text { Survey (NDTIS), } 1994 \text { 32; } \\
\text { new questions }\end{array}$ & $\begin{array}{l}\text { Consultation with Dental } \\
\text { Health Branch, NSW } \\
\text { Department of Health; } \\
\text { modification from } \\
\text { source, new questions }\end{array}$ \\
\hline Health status (1) & $0-12$ years & $\begin{array}{l}\text { Rating of child's health } \\
\text { status by respondent }\end{array}$ & SF36 $1993^{59}$ & $\begin{array}{l}\text { Question not changed } \\
\text { from source }\end{array}$ \\
\hline
\end{tabular}


TABLE 8 (continued)

SUMMARY OF QUESTION DEVELOPMENT FOR THE SURVEY INSTRUMENT, NEW SOUTH WALES CHILD HEALTH SURVEY 2001: QUESTION ORIGIN,TARGET AGE GROUP AND METHOD OF DEVELOPMENT

\begin{tabular}{|c|c|c|c|c|}
\hline $\begin{array}{l}\text { Content area } \\
\text { (number of questions) }\end{array}$ & Age group & $\begin{array}{l}\text { Specific measurement } \\
\text { elements }\end{array}$ & Source of questions & Method of development \\
\hline $\begin{array}{l}\text { Child health questionaire } \\
\text { (CHQ-PF28) (30) }\end{array}$ & $5-12$ years & $\begin{array}{l}\text { Limit in physical activity, } \\
\text { emotional or behavioural } \\
\text { problems, pain or } \\
\text { discomfort, behaviour, } \\
\text { satisfaction with self and } \\
\text { achievements, parent } \\
\text { concern about child, child } \\
\text { behaviour impact on family }\end{array}$ & $\begin{array}{l}\text { Child Health } \\
\text { Questionnaire Parent } \\
\text { Form (CHQ-PF28) }{ }^{35}\end{array}$ & $\begin{array}{l}\text { Consultation with Dr } \\
\text { Jeanne Landgraf, } \\
\text { developer of CHQ and } \\
\text { others; questions not } \\
\text { changed from source }\end{array}$ \\
\hline Respondent's health (1) & All respondents & $\begin{array}{l}\text { Self rating of health by } \\
\text { respondent }\end{array}$ & SF36 $1993^{59}$ & $\begin{array}{l}\text { Question not changed } \\
\text { from source }\end{array}$ \\
\hline $\begin{array}{l}\text { Emotional and behavioral } \\
\text { problems ( } 8 \text { ) }\end{array}$ & $4-12$ years & $\begin{array}{l}\text { Presence of emotional and } \\
\text { behavioural problems, use } \\
\text { of services, ability to } \\
\text { access services }\end{array}$ & $\begin{array}{l}\text { WA Child Health Survey } \\
1993^{27} \text {; The Mental } \\
\text { Health of Young People } \\
\text { in Australia } 1998{ }^{30}\end{array}$ & $\begin{array}{l}\text { Consultation with Centre } \\
\text { for Mental Health, NSW } \\
\text { Department of Health; } \\
\text { questions modified from } \\
\text { sources }\end{array}$ \\
\hline $\begin{array}{l}\text { Infant behavioural } \\
\text { problems (12) }\end{array}$ & $0-11$ months & $\begin{array}{l}\text { Presence of feeding, } \\
\text { sleeping or settling } \\
\text { problems, use of and } \\
\text { satisfaction with services }\end{array}$ & $\begin{array}{l}\text { Baby Health } \\
\text { Questionnaire } 198945\end{array}$ & $\begin{array}{l}\text { Modified from source; } \\
\text { new questions } \\
\text { developed }\end{array}$ \\
\hline $\begin{array}{l}\text { Toddler physical health } \\
\text { (15) }\end{array}$ & $1-4$ years & $\begin{array}{l}\text { Problems eating, walking, } \\
\text { physical problems, } \\
\text { seriousness of problem, } \\
\text { places sought help }\end{array}$ & New questions & $\begin{array}{l}\text { Newly developed; } \\
\text { loosely based on Infant } \\
\text { behavioural questions } \\
\text { and } \mathrm{CHQ}\end{array}$ \\
\hline Home visiting (6) & $0-4$ years & $\begin{array}{l}\text { Experience of home } \\
\text { visiting, acceptance }\end{array}$ & New questions & $\begin{array}{l}\text { New questions } \\
\text { developed in } \\
\text { consultation }\end{array}$ \\
\hline Parent support services (4) & $1-12$ years & $\begin{array}{l}\text { Need for and use of } \\
\text { parent support services, } \\
\text { services accessed, } \\
\text { reasons services not used }\end{array}$ & New questions & Newly developed \\
\hline Social support (6) & $0-12$ years & $\begin{array}{l}\text { Access to personal, family } \\
\text { and social support } \\
\text { networks }\end{array}$ & $\begin{array}{l}\text { National Longitudinal } \\
\text { Survey of Children, } \\
\text { Canada } 1993{ }^{57}\end{array}$ & $\begin{array}{l}\text { Consultation with Centre } \\
\text { for Mental Health to } \\
\text { select specific question } \\
\text { scale; not changed form } \\
\text { source }\end{array}$ \\
\hline Sun protection (9) & $0-12$ years & $\begin{array}{l}\text { Action to prevent skin } \\
\text { cancer, attitudes to skin } \\
\text { cancer protection, } \\
\text { frequency of sunburn }\end{array}$ & $\begin{array}{l}\text { NSW Skin Protection } \\
\text { Survey-'Seymour the } \\
\text { Snowman' } 1998^{42} \text {; NSW } \\
\text { Health Surveys, } 1997 \\
\text { and } 1998^{22} \text {; Australian } \\
\text { School Students Alcohol } \\
\text { and Drugs Survey } \\
\text { (ASSAD), } 1996^{26}\end{array}$ & $\begin{array}{l}\text { Consultation with Sun } \\
\text { protection Unit, NSW } \\
\text { Health and NSW Cancer } \\
\text { Council; modified from } \\
\text { original sources }\end{array}$ \\
\hline Sight (4) & $2-12$ years & $\begin{array}{l}\text { Normal vision, blindness, } \\
\text { use of glasses }\end{array}$ & $\begin{array}{l}\text { WA Child Health Survey } \\
1993^{27}\end{array}$ & $\begin{array}{l}\text { Minor modifications for } \\
\text { clarity }\end{array}$ \\
\hline Hearing (8) & $0-12$ years & $\begin{array}{l}\text { Normal hearing, use of } \\
\text { hearing aid, hearing loss, } \\
\text { ear infections, grommets }\end{array}$ & $\begin{array}{l}\text { ABS Child Immunisation } \\
\text { Questionnaire } 1995^{19} \text {, } \\
\text { WA Child Health Survey } \\
1993^{27} \text {, SA Health } \\
\text { Goals and Targets } \\
\text { Health Priority Areas } \\
\text { Survey } 1998^{50} \text {, } \\
\text { Pneumococcal Survey } \\
1998^{49} \text { and new } \\
\text { questions }\end{array}$ & $\begin{array}{l}\text { Consultation, modified } \\
\text { from source and newly } \\
\text { developed }\end{array}$ \\
\hline Speech (4) & $2-12$ years & $\begin{array}{l}\text { Difficulty with speech, ever } \\
\text { attended speech } \\
\text { pathologist }\end{array}$ & $\begin{array}{l}\text { WA Child Health Survey } \\
1993^{27} \text { and new } \\
\text { questions }\end{array}$ & $\begin{array}{l}\text { Modified from source } \\
\text { and newly developed }\end{array}$ \\
\hline Family functioning (12) & $0-12$ years & $\begin{array}{l}\text { Understanding, support, } \\
\text { acceptance,communication } \\
\text { problem solving, decision } \\
\text { making }\end{array}$ & $\begin{array}{l}\text { McMaster Family } \\
\text { Assessment Device } \\
1983^{34} \text { (Scale as used } \\
\text { in WA Child Health } \\
\text { Survey } 1993^{35} \text { ) and } \\
\text { National Longitudinal } \\
\text { Survey of Children, } \\
\text { Canada } 1993^{57}\end{array}$ & $\begin{array}{l}\text { Consultation to select } \\
\text { question scale. No change } \\
\text { from original questions }\end{array}$ \\
\hline
\end{tabular}


TABLE 8 (continued)

SUMMARY OF QUESTION DEVELOPMENT FOR THE SURVEY INSTRUMENT, NEW SOUTH WALES CHILD HEALTH SURVEY 2001: QUESTION ORIGIN, TARGET AGE GROUP AND METHOD OF DEVELOPMENT

\begin{tabular}{|c|c|c|c|c|}
\hline $\begin{array}{l}\text { Content area } \\
\text { (number of questions) }\end{array}$ & Age group & $\begin{array}{l}\text { Specific measurement } \\
\text { elements }\end{array}$ & Source of questions & Method of development \\
\hline Social capital (10) & $0-12$ years & $\begin{array}{l}\text { Participation in community, } \\
\text { trust and safety, relation to } \\
\text { neighbours }\end{array}$ & $\begin{array}{l}\text { Social Capital Survey in } \\
\text { five NSW communities } \\
1997^{46} \text {, plus one new } \\
\text { question }\end{array}$ & $\begin{array}{l}\text { Consultation;modified } \\
\text { from work of Onyx and } \\
\text { Bullen. }\end{array}$ \\
\hline Drowning (2) & $0-12$ years & $\begin{array}{l}\text { Ever rescued from } \\
\text { drowning, place rescued }\end{array}$ & New questions & $\begin{array}{l}\text { Consultation with Injury } \\
\text { Unit NSW Health; newly } \\
\text { developed }\end{array}$ \\
\hline Sports injury (4) & $5-12$ years & $\begin{array}{l}\text { Sports played, sports not } \\
\text { played because of injury }\end{array}$ & $\begin{array}{l}\text { NSW Youth Sports Injury } \\
\text { Survey, 1994-95 } 43\end{array}$ & $\begin{array}{l}\text { Consultation with Injury } \\
\text { Unit NSW Health; } \\
\text { modified from original }\end{array}$ \\
\hline Physical inactivity (8) & $5-12$ years & $\begin{array}{l}\text { Hours watches TV, video } \\
\text { or plays computer games }\end{array}$ & $\begin{array}{l}\text { National Longitudinal } \\
\text { Survey of Children, } \\
\text { Canada } 1993^{57}\end{array}$ & $\begin{array}{l}\text { Consultation; modified } \\
\text { from original }\end{array}$ \\
\hline School attendance (3) & $4-12$ years & $\begin{array}{l}\text { Year in at school, type of } \\
\text { school }\end{array}$ & $\begin{array}{l}\text { National Longitudinal } \\
\text { Survey of Children, } \\
\text { Canada, } 1993^{57}\end{array}$ & $\begin{array}{l}\text { Modified from original } \\
\text { and new questions } \\
\text { developed }\end{array}$ \\
\hline Preschool attendance (4) & $3-6$ years & $\begin{array}{l}\text { Ever-current attendance } \\
\text { at preschool, hours } \\
\text { attends }\end{array}$ & $\begin{array}{l}\text { National Longitudinal } \\
\text { Survey of Children, } \\
\text { Canada, 1996-97 }\end{array}$ & $\begin{array}{l}\text { Modified from original } \\
\text { and new questions } \\
\text { developed }\end{array}$ \\
\hline Child care (7) & $0-5$ years & $\begin{array}{l}\text { Ever-current use of child } \\
\text { care }\end{array}$ & $\begin{array}{l}\text { National Longitudinal } \\
\text { Survey of Children, } \\
\text { Canada } 1993^{57} \text {; } \\
\text { Blacktown Health } \\
\text { Survey } 1993^{28} \text {; WA } \\
\text { Child Health Survey } \\
1993^{27} \text {; ABS Child } \\
\text { Immunisation } \\
\text { Questionnaire } 1995{ }^{19}\end{array}$ & $\begin{array}{l}\text { Consultation and } \\
\text { modified from sources }\end{array}$ \\
\hline Smoking ETS (4) & $0-12$ years & $\begin{array}{l}\text { Smoking in household, } \\
\text { number of cigarettes } \\
\text { smoked in house, } \\
\text { forbidden child to smoke }\end{array}$ & $\begin{array}{l}\text { NSW Health Survey, } \\
1997^{22} \text {; Quit Evaluation } \\
\text { Studies } 1998^{38} \text {; } \\
\text { Smoking among school } \\
\text { students in Central and } \\
\text { South Western Sydney } \\
1998^{48}\end{array}$ & $\begin{array}{l}\text { Consultation; modified } \\
\text { from source and new } \\
\text { question }\end{array}$ \\
\hline Smoking in pregnancy & $0-11$ months & $\begin{array}{l}\text { Smoked in pregnancy, } \\
\text { frequency and quantity, } \\
\text { behaviour change in } \\
\text { relation to trimeseter }\end{array}$ & $\begin{array}{l}\text { Midwives Data } \\
\text { Collection, NSW } \\
\text { Department of Health } \\
1999^{24}\end{array}$ & Modified from source \\
\hline Demography (41) & $0-12$ years & $\begin{array}{l}\text { Residents of household, } \\
\text { parent and child place of } \\
\text { birth-Aboriginal and Torres } \\
\text { Strait Islander origin, } \\
\text { language spoken at } \\
\text { home, parent education } \\
\text { and employment, benefits, } \\
\text { place resident and length } \\
\text { of time resident, housing, } \\
\text { health insurance }\end{array}$ & $\begin{array}{l}\text { NSW Health Surveys, } \\
1997 \text { and } 1998 \text { 22; New } \\
\text { questions }\end{array}$ & $\begin{array}{l}\text { Modified from sources; } \\
\text { new questions } \\
\text { developed }\end{array}$ \\
\hline
\end{tabular}

